\title{
A strange kind of Kantian: Bakhtin's reinterpretation of Kant and the Marburg School
}

Sergeiy Sandler

Studies in East European Thought, 67(3/4), 2015.

The final publication is available at Springer via http://dx.doi.org/10.1007/s11212-015-9237-2.

\begin{abstract}
This paper looks at the ways in which Mikhail Bakhtin had appropriated the ideas of Kant and of the Marburg neo-Kantian school. While Bakhtin was greatly indebted to Kantian philosophy, and is known to have referred to himself as a neo-Kantian, he rejects the main tenets of neoKantianism. Instead, Bakhtin offers a substantial re-interpretation of Kantian thought. His frequent borrowings from neo-Kantian philosophers (Hermann Cohen, Paul Natorp, and others) also follow a distinctive pattern of appropriation, whereby blocks of interconnected ideas are removed from their original context, and made to serve Bakhtin's own—substantially different—philosophical purposes in the context of his own thought. Bakhtin's thought thus remains original even as he is borrowing ideas from others.
\end{abstract}

Keywords. Bakhtin, Mikhail; Kant, Immanuel; Cohen, Hermann; Natorp, Paul; neo-Kantianism; intellectual history.

This paper offers a re-examination of the role Kantian and neo-Kantian philosophy played in the formation of Mikhail Bakhtin's thought. This re-examination will provide a glimpse into the ways in which Bakhtin incorporated other people's ideas into his own philosophy. More broadly, Bakhtin's example can give us some insight into what it means to be an original thinker, and how stark originality can coexist with borrowing ideas from others - indeed, can even be manifest in how ideas are borrowed.

For several decades now, a central focus in Bakhtin scholarship has been the discovery of various influences on Mikhail Bakhtin's thought (and on the work of other members of the Bakhtin Circle). Within this trend, pride of place among the sources studied has been given to the German neo-Kantian philosophy of the late $19^{\text {th }}$ and early $20^{\text {th }}$ centuries, and in particular to the Marburg School of neoKantianism and its central figures-Hermann Cohen, Paul Natorp, and Ernst Cassirer. Marburg neoKantianism is well established as a major influence on Bakhtin. A stronger argument has also often been made that Bakhtin should simply be considered a (Marburg) neo-Kantian himself, at least in some significant respects (this appears to be the position of Poole 1995, and, with some caveats, of Brandist 2002a, b). ${ }^{1}$

${ }^{1}$ Another position (e.g., Morson and Emerson 1990, pp. 64-65) views only Bakhtin's early philosophical work (Bakhtin 1990 [1923/4], 1993 [1921/2]) as heavily influenced by neo-Kantianism-an influence which Bakhtin then mostly overcomes. As I will argue in what follows, Bakhtin's rather unorthodox attitude toward neo-Kantianism is already evident in his earliest writings. 
To be sure, there is a strong case to be made for such a reading of Bakhtin. We know Bakhtin read Kant and Cohen at a young age (Bakhtin $2002[1973]^{2}$, pp. 40-41) and was clearly greatly impressed by this reading (his familiarity with neo-Kantianism is also evident from his writings). As late as 1973, he could speak of his "partiality for the Marburg School" (Bakhtin 2002 [1973], p. 45). Tellingly, what we now call "The Bakhtin Circle" started off as a "Kant seminar" in the provincial town of Nevel' in 1918 (see, e.g., Brandist et al. 2004, p. 256). Bakhtin's co-founder of this seminar and close friend, Matvej Kagan, also provides a biographical link with the Marburg School: at the time he just returned from Germany, where he studied with all major figures of Marburg neoKantianism, and was highly regarded by his mentors (Kagan 2004a [1922], b [1924/5]; Poole 1997). Kagan was clearly instrumental in exposing young Bakhtin to the latest works and ideas emanating from Marburg at the time. We even have Bakhtin's own word (Bakhtin 2002 [1973], pp. 161-163), corroborated by the memoir of a witness (Mirkina 1993 quoted in Melixova 2000, p. 567) to testify that - at least in the early 1920s - he indeed considered himself to be a Kantian or neo-Kantian, and referred to himself as such. ${ }^{3}$

One could have sealed the argument at that, were it not for what Bakhtin actually wrote. A look at his writings, however, substantially problematizes any attempt to assimilate him to the Marburg School (or to its rival within neo-Kantianism, the Baden School, for that matter). Bakhtin's unfinished philosophical treatise, the surviving fragment of which was published posthumously under the title Toward a Philosophy of the Act (Bakhtin 1993 [1921/2]), is especially telling in this respect. It was written, almost certainly, in the height of Bakhtin's period of self-reported "zealous" Kantianism. ${ }^{4}$ And yet, as we shall see, this text is a sustained philosophical assault on the very principles of neoKantian philosophy. It turns out that Bakhtin of the early 1920s was a very strange kind of neoKantian.

In what follows, I will offer a solution to this puzzle and look at some of the consequences of this solution. In the next section, I will summarize Bakhtin's critique of Marburg neo-Kantianism. Following that, I will examine Bakhtin's treatment of Kant himself and explore the possibility that he

\footnotetext{
${ }^{2}$ A note on dating references to Bakhtin's works. The date included in square brackets reflects either: a. the publication date of the Russian original for Bakhtin's few lifetime publications; b. the writing date of texts published posthumously, as estimated in the commentary to the (currently) definitive Russian edition (Bakhtin 1996-2012); or c. the date of recording for interviews with Bakhtin. A similar rule applies to citing works by Matvej Kagan.

${ }^{3}$ But note that Bakhtin's wording implies a certain distance: "I was such a zealous [zaiadlyj] Kantian", he recalls of himself in the first half of the 1920s (Bakhtin 2002 [1973], p. 161). But zaiadlyj is a pejorative term, which implies that at least by 1973, when the quoted interview was recorded, he no longer considered himself to be as zealous a Kantian as he was back then.

${ }^{4}$ Bakhtin's early philosophical writings are difficult to date with precision. Traditionally, proposed dates have ranged from 1918 to 1924 (e.g., Clark \& Holquist 1984, p. 63 ff). One noted scholar (Poole 2001) argued for a somewhat later dating of 1926 to 1928, but see Nikolaev and Liapunov (2003, pp. 495-503) for a refutation and solid arguments in favor of dating "Author and Hero in Aesthetic Activity" (Bakhtin 1990 [1923/4]) to 1923-1924. Gogotišvili (2003, pp. 412-418) argues for roughly 1921-1922 as the date range for Toward a Philosophy of the Act. Be that as it may, it is agreed that Toward a Philosophy of the Act is an early work, which one would have expected to be neo-Kantian in character.
} 
was in effect trying to establish his own strand of "neo-Kantian" philosophy, distinct from any of the extant neo-Kantian schools of the time (and much closer to what later would become known as Existentialism). I will then return to some of the ideas and concepts Bakhtin did borrow from the Marburg School, and will trace the rather peculiar way in which these borrowings are recontextualized as they become integrated into Bakhtin's own philosophical scheme.

\section{Bakhtin's critique of Marburg neo-Kantianism}

As noted above, Bakhtin openly acknowledged his indebtedness to neo-Kantian philosophy and the Marburg School, as well as specifically to the work of Hermann Cohen ("He was a remarkable philosopher, who has had an immense influence on me"-Bakhtin 2002 [1973], p. 40). In Toward a Philosophy of the Act Bakhtin also makes clear that he holds neo-Kantianism in great esteem (Bakhtin 1993 [1921/2], p. 19), but this positive evaluation appears in a clearly critical context.

Bakhtin's early philosophical manuscripts contain explicit criticisms of Cohen and of other neoKantians, and indeed of Kant himself (Bakhtin 1990 [1923/4], pp. 66-81, 210; Bakhtin 1993 [1921/2], pp. 6, 21-22, 34), as well as an explicit rejection of the whole enterprise of Kantian ethics, at least as traditionally understood (Bakhtin 1993 [1921/2], pp. 25-27). But this in itself may not be conclusive. After all, neo-Kantian philosophers often criticized one another, and suggested correctives to Kant's philosophy. Moreover, by the early 1920s, neo-Kantianism was rapidly disintegrating, and younger philosophers brought up within the neo-Kantian tradition were developing away from the neo-Kantian movement (see, e.g., Dmitrieva 2007).

Still, Bakhtin's critique of neo-Kantianism deals not with some of its secondary aspects (we will see later that it is actually the secondary aspects that Bakhtin willingly absorbed), but with the very heart of the philosophical system proposed by Cohen and his followers. Bakhtin was happy to credit neo-Kantianism with achieving "great heights and [...] be[ing] able, finally, to work out perfectly scientific methods" (Bakhtin 1993 [1921/2], p. 19), but in the very same paragraph he denied it, and modern philosophy in general, the foundational status of "first philosophy" (Bakhtin 1993 [1921/2], p. 19) - the status of ultimate validity without which any philosophical system loses its ground.

Furthermore, the critique of neo-Kantianism is not a side affair for Bakhtin. Toward a Philosophy of the Act (at least to judge by the fragment of it that has reached us) is concerned with refuting the fundamental tenets of neo-Kantianism as a central endeavor. To show that this is the case, let me take a brief detour and devote a few paragraphs to a (necessarily superficial and only partly adequate) summary of what Marburg neo-Kantianism was trying to achieve, a summary that, inevitably, has to begin with Immanuel Kant himself.

In his Critique of Pure Reason, Kant (1929) [1781/7] offered a fundamentally new approach to metaphysics for his time, a "Copernican revolution" that bypassed the appearance vs. reality dilemma that European philosophy was concerned with since Descartes. Kant argued that we see the world not directly as it is, but in a way determined by how we perceive and conceive of things. The world of 
phenomena - that is, the world as it appears to us - is thus constituted by the way subjects are formed. Nevertheless, this world of phenomena is not thereby reduced to the status of a mere illusion, the byproduct of a human psychological habit (as David Hume might have put it). For Kant, subjects as such have a certain common form, through which we all share the pure intuitions of space and time and the categories of pure reason. Phenomena may be appearances, but they are nevertheless objective, the same for all. This common form of subjects also explains the objective validity of the laws of nature, as revealed by various sciences.

In an important sense, then, the phenomena consciousness faces are constituted by the form of this very consciousness. This insight was central to the way Kantian thought developed in $19^{\text {th }}$-century German philosophy, including neo-Kantian philosophy. The central metaphysical claim of neoKantianism is that the world of phenomena is constituted by the theoretical sciences, which are, in turn, grounded in logic (Brandist 2002a, pp. 16-18; Kagan 2004d [1922], pp. 203-204). Now, one may wonder: if sciences constitute the very world they study, how is scientific discovery possible? For Kant himself, the source of scientific discovery is, in the final account, the world of things in themselves. But later philosophers were keenly aware of the contradiction such a reply would entail. After all, on Kant's own account, the world of things in themselves is unknowable. Hermann Cohen and his followers offered a different-more idealistic, but also more complex-answer to this question. For the Marburg neo-Kantians, the constitution of the world by science and reason is a task that has not yet been completed, and that cannot in principle be completed. The complete constitution of the world of phenomena is an ideal posited before us. Scientific discovery is the process through which we asymptotically approach this ideal without fully achieving it. In it, sciences follow a trajectory set out by the logical principles underlying them.

Coming back to Bakhtin, in Toward a Philosophy of the Act he makes a radical break from modern philosophical tradition, neo-Kantianism included. At the center of the philosophical alternative Bakhtin offers stands what he calls the deed (postupok). ${ }^{5}$ This term has a clear German equivalent in the writings of neo-Kantian philosophers: Handlung. ${ }^{6}$ But an equivalence in terminology does not yet indicate equivalence in substance - a point that we will have a few more opportunities to observe in relation to Bakhtin's appropriation of others' work (Nikolaev 2001, pp. 198-200; Sandler 2012). Instead, the notion of the deed has different philosophical roots and an independent claim for

\footnotetext{
${ }^{5}$ Vadim Liapunov's English translation (Bakhtin 1993 [1921/2]) uses both "deed" and "act" (as in the title of the work), and often even uses the phrase "act or deed" to render the same Russian word. I will consistently use "deed" as the translation of postupok, because of the everyday ethical connotations this word shares with its Russian counterpart (e.g., in such expressions as "good deeds" and "bad deeds").

${ }^{6}$ See, for example, its use in the fragment from Natorp's Sozial Idealismus discussed below. Notably, Kagan's Russian translation of that book indeed renders Handlung as postupok (Natorp 2004 [1920], pp. 148149).
} 
the foundational philosophical status Bakhtin grants it. Bakhtin uses this concept to express the actuality of my first-person perspective on, stance toward, and engagement in the world. ${ }^{7}$

Consider some of Bakhtin's own examples for illustrating this point. Suppose I am facing a moral dilemma. Various kinds of information and bodies of theoretical knowledge can help me compare the different options, and while I am thus deliberating, the different horns of the dilemma I am facing are on the same plane, as it were. But then I make my choice, follow through on one particular course of action, and this equivalence between the horns disappears. For now I have actually done a deed, and cannot undo it. I am responsible for what I did and for the consequences of what I did, but I am not responsible for any of the things I considered, but did not do (cf. Bakhtin 1993 [1921/2], pp. 28-29).

My deeds, thus, are actual, real, but Bakhtin's point here is not about their objective reality. On the contrary, he aims to show the secondary, derived, status of objectivity (Bakhtin 1993 [1921/2], pp. 29-30). Consider a document, which states that I undertake a commitment to do this or that thing (Bakhtin 1993 [1921/2], pp. 38-39). We can analyze the document's content to state what it is exactly that I am said to have done. But the fact that such a text exists and objectively states that I take on doing so-and-so does not yet constitute a commitment on my part to do anything. For this to be a real commitment I need to indeed commit to do what is stated, for example by signing the document (Bakhtin does not mean the formality of adding a signature — which may be forged, coerced, added in jest or otherwise insincerely; the signature is a stand-in for the actual deed of committing). If I actually do make this commitment, the actuality of my commitment is a deeply subjective actuality; it is not something accessible to public view. And yet, only the subjective fact of committing can give the objectively-verifiable content of the document its force.

Moreover, the same objective action can (indeed must) have different meanings for different individuals. Analyzing a poem by Puškin (Bakhtin 1993 [1921/2], pp. 65-73; Bakhtin 1990 [1923/4], pp. 211-221), Bakhtin refers to a journey undertaken by one of the characters. For her, this journey is a journey back home from abroad. For her lover (the poem's lyrical $I$ ), this is a journey of his beloved away from him, to a foreign land (foreign to him). These are two different deeds, even as, objectively speaking, both relate to the same person traveling on exactly the same trajectory in space and time.

Bakhtin's claim - flying in the face of millennia of philosophical tradition —is that philosophical primacy and ultimate reality should be assigned not to the one objective description of this journey, but to the two different subjective deeds. Both subjective deeds refer to the trajectory objectively travelled by the poet's beloved, include it as part of them. But from the objective trajectory there is no way to deduce how each character felt, how this trajectory could be plotted using such subjective, perspective-bound coordinates as "home" and "abroad", "near" and "far", how space and time, and

\footnotetext{
${ }^{7}$ Like Bakhtin himself, I am using the first person singular (" $m y$ ") in this description to stress the essential difference between this actuality and the potential, hypothetical status of general theoretical claims. Statements about "a subject", "a person", "a self", etc. hold potentially for abstract entities; statements about me hit closer to home. The idea is for readers to adhere, for the purposes of our discussion, to the same linguistic practice, and to examine these points as applying to them, personally.
} 
objects in space and time, were perceived by the traveler when she was making her journey. A philosophy grounded in the deed can thus be complete, also having access to objective reality, but a philosophy grounded in objectivity is incomplete, has no access to the reality of the deed, of individual experience. The variable deeds underlie the invariant objective content, not the other way around.

A clear philosophical precedent for this move Bakhtin is making here can be found in Kierkegaard's arguments for the precedence of subjectivity to objectivity and of existence to possibility (Kierkegaard 1992 [1846]), arguments with which Bakhtin was well familiar (Bakhtin 2002 [1973], pp. 41-43). ${ }^{8}$ I should emphasize that — while Kierkegaard was an important influence on Bakhtin in this respect-Bakhtin's development of the themes in question significantly departs from Kierkegaard's own. Also, some of these Kierkegaardian themes, if not with the same level of philosophical clarity, could also have been familiar to Bakhtin from a broader tradition in $19^{\text {th }}$ - and early $20^{\text {th }}$-century philosophy. Max Scheler might be a relevant figure (cf. Poole 2001), as is Max Stirner (Nikiforov 2006, pp. 323-340). Some relevant themes can even be found in the work of Baden School neo-Kantians (in particular of Heinrich Rickert-see again Nikiforov 2006), though, as we shall see, the overall philosophical content of neo-Kantianism cannot be reconciled with the reversal of philosophical priorities Bakhtin is advocating in Toward a Philosophy of the Act.

So, early Bakhtin is arguing for a philosophy firmly grounded in the deed (and through the deed, in the architectonics of self-other relations - a crucial step in Bakhtin's philosophy, which I only have space to touch very briefly on below). But he also passionately argues against something. This something he polemicizes with, Bakhtin refers to as "theoretism" (e.g., Bakhtin 1993 [1921/2], pp. 11-13). ${ }^{9}$ The term "theoretism" refers to a broad array of philosophical approaches that only recognize the reality of objective content, and remain necessarily blind to the particularity of the deed. But it is not hard to see which philosophical school in particular Bakhtin had in mind when he coined the term. The reference to the status of the theoretical sciences in neo-Kantianism, especially Marburg neo-Kantianism, is obvious. The broad philosophical critique in Toward a Philosophy of the Act has Hermann Cohen and his disciples in its focus.

And note that this polemic against neo-Kantianism can often conflict with its target's self-image. Thus, a critique of philosophical rationalism is one of the pillars on which Kant's philosophy stands. Neo-Kantians followed suit in rejecting rationalism. Bakhtin's take on rationalism is equally negative, but note the wording:

All of modern philosophy sprang from rationalism and is thoroughly permeated by the prejudice of rationalism (even where it consciously tries to free itself from this prejudice) that only the logical is

\footnotetext{
${ }^{8}$ For more on Bakhtin and Kierkegaard see, e.g., Fryszman (1996) and Ščittsova (1999).

${ }^{9}$ Or "theoreticism" in the published English translation. The Russian original is teoretizm.
} 
clear and rational, while, on the contrary, it is elemental and blind outside the bounds of an answerable consciousness, just as any being-in-itself is (Bakhtin 1993 [1921/2], p. 29; italics added).

The jab I italicized alludes to the status of logic in constituting the objective world of phenomena on the Marburg account. What we have here is thus not another neo-Kantian critique of rationalism, but a critique of neo-Kantianism as itself embodying the "prejudice of rationalism" it purports to reject.

Similarly, Bakhtin fully accepts the Kantian principle of the primacy of practical reason (i.e. ethics) over pure reason (i.e. metaphysics). But he is much less impressed with neo-Kantians' level of adherence to this principle they claim to profess (Bakhtin 1993 [1921/2], pp. 21-22, 27).

So, to recapitulate, Bakhtin's early work is a sustained polemic against the very foundations of the neo-Kantian doctrines of the day, coming from a thinker who refers to himself as a neo-Kantian at that very time. To understand what is going on here, let us now turn to (some of) Bakhtin's treatment of Kant himself.

\section{To Kant and beyond}

Interestingly, for a self-avowed Kantian, there are not too many references to Kant in Bakhtin's work. I am going to look at just two, but these two references are particularly telling - they allow us to see not only how Bakhtin viewed Kant, but also how his reading of Kant connects to his own philosophy. In both cases, Bakhtin is referring to examples Kant uses to illustrate his philosophical argument - the comparison between a hundred thalers in one's pocket and in one's imagination, and his incongruous counterparts argument.

Let us first look at the point Kant is making.

A hundred real thalers do not contain the least coin more than a hundred possible thalers. For as the latter signify the concept, and the former the object and the positing of the object, should the former contain more than the latter, my concept would not, in that case, express the whole object, and would not therefore be an adequate concept of it. My financial position is, however, affected very differently by a hundred real thalers than it is by the mere concept of them (that is, of their possibility). For the object, as it actually exists, is not analytically contained in my concept, but is added to my concept (which is a determination of my state) synthetically; and yet the conceived hundred thalers are not themselves in the least increased through thus acquiring existence outside my concept (Kant 1929 [1781/7], p. B627).

The hundred thalers example is part of Kant's rebuttal of the ontological proof of God's existence, which proceeds as follows: The concept of God is a concept of the most perfect being; not to exist would have been an imperfection, so would contradict the concept of God; therefore, God has to exist. Kant's reply is that existence is not a property, not a predicate, and so non-existence is not an imperfection. As part of this argument, Kant offers us to imagine a hundred thalers-a hefty sum of 
money in his day. These imagined hundred thalers are worth exactly one hundred thalers. A hundred thalers in one's pocket are not worth a penny more than that by virtue of existing. It's just that the money in my imagination leaves me no richer than I am without it.

The incongruous counterparts argument deals with the nature of space:

What indeed can be more similar to, and in all parts more equal to, my hand or my ear than its image in the mirror? And yet I cannot put such a hand as is seen in the mirror in the place of its original; for if the one was a right hand, then the other in the mirror is a left, and the image of the right ear is a left one, which can never take the place of the former. Now there are no inner differences here that any understanding could merely think; and yet the differences are inner as far as the senses teach, for the left hand cannot, after all, be enclosed within the same boundaries as the right (they cannot be made congruent), despite all reciprocal equality and similarity; one hand's glove cannot be used on the other. What then is the solution? These objects are surely not representations of things as they are in themselves, and as the pure understanding would cognize them, rather, they are sensory intuitions, i.e., appearances, whose possibility rests on the relation of certain things, unknown in themselves, to something else, namely our sensibility (Kant 2004 [1783], pp. 37-38).

The mirror image or gloves example is thus part of Kant's argument that space and time are not properties of things in themselves either. In Kant's own words:

All those who cannot yet get free of the conception, as if space and time were actual qualities attaching to things in themselves, can exercise their acuity on the following paradox, and, if they have sought its solution in vain, can then, free of prejudice at least for a few moments, suppose that perhaps the demotion of space and of time to mere forms of our sensory intuition may indeed have foundation (Kant 2004 [1783], p. 37).

If space were a property of things in the world, then two objects identical in their internal spatial relations would always be able to occupy the same space. My two hands are not significantly different from one another in their internal spatial relations, and yet, they can never occupy the same space, because - to use a technical term - they differ in their chirality: one is a left hand and the other a right. We should therefore admit that space is not a property of things themselves.

Kant's discussion of both these examples is representative of his philosophical position. Things in the world, like the hundred thalers, exist independently of our cognition, but their perception is essentially shaped by our faculties, which alone place them, for example, in space. Subjectivity is thus - for the first time in Western thought-recognized as constituting objective reality (as we perceive it).

But if we now come back to Bakhtin's take on these Kantian examples, we find them transferred into a rather different philosophical context. To begin with, Bakhtin's incongruous counterparts are not objects in space: 
From the "objective" point of view there is a human being, a person, etc., but the difference between the I and the other is relative: everybody and anybody is an I, everybody and anybody is an other. An analogy with the irrational distinction between the right and the left glove, between an object and its mirror image. Nevertheless, the I feels itself to be an exception, the only I in the world (all the others are others) and lives this opposition (Bakhtin 1996b [1943-6], p. 73).

The essential asymmetry between I and others is a central theme-perhaps the central theme- of Bakhtin's philosophy, especially in his early period. ${ }^{10}$ Kant's incongruous counterparts argument is used here to argue for this asymmetry and from it. Just as Kant used the right and left hand to argue against an "objective" view of space as independent of the subject, Bakhtin uses the I-other asymmetry to argue against an "objective" view of subjects as equivalent, as reducible to a general category or form in which they all partake. So, in a sense, it is an argument against Kant: yes, the other and I are both subjects, with all the common faculties emphasized by Kant, and yet, another cannot stand in my place, cannot become $m e$, and I cannot stand in another's place, cannot stop being me.

Kant's hundred thalers argument is enlisted for Bakhtin's purposes in Toward a Philosophy of the Act in a more direct manner:

One can observe a peculiar lightening of the very term "Being" or "Reality." Kant's classical example against the ontological proof, that a hundred real thalers are not equal to a hundred thinkable thalers, has ceased to be convincing. What was historically on hand once and only once in the reality that was determined by me in a once-occurrent manner is, indeed, incomparably heavier. But when it is weighed on theoretical scales (even with the addition of a theoretical constatation of its empirical existence) in detachment from its historically valuative uniqueness, it is highly unlikely that it will prove to be heavier than what is merely thinkable (Bakhtin 1993 [1921/2], p. 8).

On the surface, there is one conspicuous discrepancy between Kant's example and Bakhtin's reading of it. Kant insists the real and thinkable thalers are exactly equal in worth, while Bakhtin presents Kant as saying the real and thinkable thalers are not equal. On a closer look, though, we may note that Bakhtin claims the real thalers differ from the imagined ones not in the amount of money there, but in weight. By restating Kant's argument in this way, Bakhtin achieves a shift of emphasis. For Kant, the point of the example is to show existence is not among an object's properties; for Bakhtin, it is more important to stress the precedence of existence over possibility (and cf. Kierkegaard 1992 [1846] again), and the fact that existence is inaccessible to theory-hence the weight of the real, and the "theoretical scales", on which this weight just doesn't register.

Bakhtin, of course, agrees with Kant that existence is not a predicate, but he has a rather different notion of "existence" in mind. Kant is speaking about the existence of an object in the world, about

${ }^{10}$ The quote above is from notes Bakhtin wrote (probably) considerably later, in the early 1940s, but it deals with topics developed most thoroughly in his earliest works. 
whether it is there or not. For Bakhtin, this notion of existence is secondary. His primary notion of existence he describes in this quote as "What was historically on hand once and only once in the reality that was determined by me in a once-occurrent manner". As in the incongruous counterparts argument, Bakhtin's point here again has to do with my first-person experience and perspective; not with the existence of objects, but with human existence. This is the notion of existence that would later come to be identified with existentialist philosophy, and with which Bakhtin was well familiar from his reading of Kierkegaard.

What transpires from the passages we examined is that Bakhtin, in effect, had his own take on Kant's "Copernican revolution". Kant found the solid ground on which he could rebuild and fortify objective reality in the subject. But Kant was talking about the subject in general, about the universal form and faculties of subjectivity that he assumed are common to us all. Bakhtin, on the other hand, seeks the ground for constituting reality in the concrete and individual subject, in the immediate actuality of $m y$ first-person experience, perspective, and activity.

For Kant, the objectivity of the world of phenomena, the world as it appears to us, amounts to intersubjectivity - it is objective because it appears in the same "format" to all observers. But Kant's intersubjectivity is symmetric and uniform, and therefore empty: all subjects are essentially the same and can therefore in principle be replaced by a simulation. I need no actual other people, no actual perspectives that are not my own, to constitute the world or indeed my own subject, because whatever is available to others is also, in principle, available to me. Bakhtin, on the other hand, insists on the asymmetrical nature of intersubjectivity, on the irreducibility of my perspective to others' and of others' to mine. I constitute the world as an object, but others constitute $m e$ as a subject. ${ }^{11}$

By now it should be clear in what sense Bakhtin could refer to himself as a neo-Kantian: A neoKantian in this sense is not a member of one of the neo-Kantian schools, not a disciple of Cohen or Windelband, but rather a philosopher who-like Cohen or Windelband-accepts the foundational status of Kant's Copernican revolution but seeks to extend it, go beyond it, and thus also against some aspects of it. The direction in which Bakhtin sought to extend Kant was starkly different from the direction chosen by his predecessors. So, in a way, Bakhtin could be said to have created his own brand of neo-Kantianism.

\section{Cohen and Natorp in Bakhtin's philosophical pastiche}

An important part of our puzzle about Bakhtin and neo-Kantianis can thus be considered solved. But some questions still remain open. Recall Bakhtin's references to the Marburg School and to Cohen in particular, which I cited above. We can note that in Toward a Philosophy of the Act the critique of

11 To briefly recapitulate this central philosophical move of Bakhtin's here-he argues for the intersubjective constitution of the subject by problematizing the notion of introspection, central to Western philosophy from Descartes on. As Bakhtin insists (e.g., Bakhtin 1990 [1923/4], pp. 27-36), I cannot form a coherent image of myself as an entity in the world. I can be in another person's field of vision, but not in my own. And therefore, I need to be able to communicate with others, to receive my exterior image from them, in order to become a full-fledged subject myself. 
Marburg philosophers is expressed in a generally reverential tone, and that Cohen could have influenced Bakhtin by his example as a "renewer" of Kant, more than by the particulars of his philosophy. Both points are relevant, as is the observation that Marburg philosophers' influence on Bakhtin was extensive but secondary in its impact on the fundamental thrust of his thought.

Still, there are particular borrowings from Marburg neo-Kantians we can point to, and these borrowings are interesting to examine. What I think makes them so interesting is that they bring to light Bakhtin's unusual way of treating other people's work, his specific pattern of appropriation, which remains characteristic of Bakhtin's writings in all periods of his work. ${ }^{12}$ In this paper I will consider two specific case studies, each with an additional little mystery to solve around it, one linked to the work of Hermann Cohen, and the other to that of Paul Natorp.

\section{The uniqueness of God and the uniqueness of me}

Here's a little mystery. A central term in Bakhtin's early work, and in Toward a Philosophy of the Act in particular, is edinstvennost' (and the corresponding adjective, edinstvennyj). Vadim Liapunov (in Bakhtin 1993 [1921/2]) translated this term as "once-occurrence". Another translation was proposed by Vladimir Nikiforov (2006): the adjective edinstvennyj in Russian simply means "the only", so the noun could be rendered as "only-ness". As we shall see, an even better translation could be "uniqueness".

But Bakhtin does find a strange use for such an ordinary word. "Uniqueness" is Bakhtin's epithet for the ultimate reality of a person's ( $m y$ ) first-person perspective and deeds. I am the only I, my deeds are unique, the reality constituted by my deeds is unique. This uniqueness is compared to, and found heavier than, the unity of theoretical and scientific knowledge and of objective reality itself. We also saw these uses of edinstvennost' in both Kant-related Bakhtin quotes discussed above.

So, where does this rather unusual twist on the simple word "only" come from? Nikiforov (2006) suggests the influence of Max Stirner's mid-19 $9^{\text {th }}$-century work The Ego and Its Own. This may well be true too, but I would like to suggest a rather obvious alternative source: Hermann Cohen's last book, Religion of Reason Out of the Sources of Judaism (Cohen 1972 [1919])—a work that was well known to Bakhtin and his friends early on (there is a very detailed summary of it prepared by Matvei Kagan at the time-see Kagan 2004c [1920/1]).

Of course, there is a little twist. Cohen's use of "uniqueness" makes good sense, because for Cohen this epithet applies (at least originally) not to the human individual, but to God (Cohen 1972 [1919], pp. 35-49). In monotheism there is only one God: Cohen (1972 [1919], p. 35) explicitly contrasts the oneness of God, central to Christianity and even more so to pantheism, with the Judaic notion of the uniqueness of God, which for him is the true hallmark of monotheism. This uniqueness

${ }^{12}$ For some relevant observations in the literature, see Nikolaev's (2001, pp. 198-200) discussion of how Bakhtin transformed the neo-Kantian notion of responsibility (or answerability), Sandler's (2012) examination of Bakhtin's linguistic terminology and numerous discussions in Gogotišvili's (1996) commentary to several of the texts published in vol. 5 of Bakhtin's Collected Writings. 
of God has some consequences, which Cohen explores. To keep things brief, I'll note two such consequences and the way they link to Bakhtin's early philosophy. A comparison of Cohen's Religion of Reason with Bakhtin's Toward a Philosophy of the Act and other early works will easily reveal several other parallels, on which space does not allow me to dwell.

One of these two consequences has to do with the creation of the world. In polytheistic creation myths, the making of different things in the world is divided between the different deities. In monotheism, there is only one God, and it follows that this one God created the world in its entirety, as indeed the biblical account in Genesis 1 teaches. The other consequence has to do with God's image, or rather lack thereof. In the text of the biblical Ten Commandments, the verse: "Thou shalt have no other gods before me" (Exodus 20:3) is immediately followed by the verse "Thou shalt not make unto thee any graven image, or any likeness" (Exodus 20:4). An image of the unique monotheistic God - Cohen insists - is not only sacrilegious, but impossible, because an image of God would itself violate the condition of uniqueness, would potentially become another divinity in its own right (Cohen 1972 [1919], p. 53).

When Bakhtin speaks of uniqueness, it is the uniqueness of the person (my uniqueness) that he is talking about, not the uniqueness of God. However, some attributes of uniqueness in Cohen's account survive the transition. Thus, as you might recall, Bakhtin describes the human individual (me) as constituting a world, the world of my deeds. This world-constituting ability I possess not as a Kantian generalized subject, but as a unique individual, as the only I in the world. The parallel with the unique God-creator in Cohen's account is evident. Even more striking is the connection between uniqueness and the impossibility of creating an image of the unique. A staple of Bakhtin's philosophy in all periods is my inability to obtain a coherent image of myself (e.g., Bakhtin 1990 [1923/4], pp. 27-36; Bakhtin 1996a [1943]). It is this impossibility that disrupts the Cartesian constitution of the subject through introspection and allows Bakhtin to argue for my essential dependence on others - the ground on which his dialogic philosophy stands.

Note that Bakhtin seems to adopt whole chunks of philosophical tissue from Cohen here. The reasoning that leads from the uniqueness of God to the impossibility of creating an image of God in Cohen's account does not apply to human subjects. Instead, Bakhtin offers his own philosophical arguments to support these conclusions, but he preserves the internal conceptual connections he found in Cohen nevertheless.

On the other hand, Bakhtin can also be very selective in what he chooses to "copy" from Cohen's system. For Cohen (1972 [1919], p. 86), when in Genesis 2 the bible states man and woman were created in the image of God, he interprets this "image" as reason (which also hearkens back to Kant's view of reason as part of that universal form of subjects common to us all, and which more than smacks of theoretism in Bakhtin's lexicon). Bakhtin identifies God primarily with the role of the other. And while the notion of the other, the thou, even as a specifically religious notion, is present in Cohen's philosophy as well, for Cohen the $I$ and the thou strive to merge in the messianic vision of 
universal community (Cohen 1972 [1919], pp. 236-278). Bakhtin rejects the possibility of such a merger.

What Bakhtin does with Cohen's notion of uniqueness is combine it into his own philosophy by applying a pastiche technique of sorts. This is actually typical of how Bakhtin appropriates others' ideas. Cohen's concept preserves much of its form and its connections with other notions - even quite arbitrary ones-but is transferred by Bakhtin into a substantially different context and is made to bring a significantly new philosophical import into the fabric of Bakhtin's own thought. The patch of imported fabric becomes interwoven with other patches and threads to form the tapestry of Bakhtin's own original thought.

\section{Logos and the missing dialogue}

A central concept in Bakhtin's philosophy, especially in his book on Dostoevsky (Bakhtin 1984 [1929/1963]) and related texts, is dialogue. It is also one of the concepts most closely identified with Bakhtin (see, e.g., Holquist 1990). However, "dialogue" as a philosophically significant term is entirely absent from Bakhtin's earliest works. This is not because Bakhtin's early philosophy is not dialogical. ${ }^{13}$ It is, of course, quite possible that Bakhtin simply did not yet think of using the word "dialogue". And it is true that the term enters Bakhtin Circle texts first in a linguistic context (Voloshinov 1986 [1929]), under the clear influence of Lev Jakubinskij's 1923 article "On Dialogic Speech" (Yakubinsky 1997 [1923]). ${ }^{14}$ Still, I would like to open up the possibility that the term "dialogue" was not simply absent from Bakhtin's early works, but was actively avoided, and that the new contexts in which Bakhtin could find the term after 1923 in Jakubinskij (Yakubinsky 1997 [1923]) and Buber (1970) [1923] did more than just bring the word "dialogue" to Bakhtin's mind; they legitimized this concept by freeing it from associations Bakhtin found to be unacceptable.

My evidence for this claim comes in the form of a passage from Paul Natorp's late book SozialIdealismus (Natorp 1920), which I am quoting below at some length. Bakhtin was almost certainly familiar with this passage. He was clearly following new work coming out of Marburg at the time, as was his friend, Matvej Kagan. For this particular book of Natorp's, Kagan prepared a complete Russian translation, which he hoped to publish at the time (it was eventually only published, with omissions, as Natorp 2004 [1920]). ${ }^{15}$ I should, however, add the important caveat that the themes Natorp brings up in this passage could well have been already familiar to Bakhtin from other works

\footnotetext{
${ }^{13}$ It is true that the completion ("consummation", "finalization"; the Russian word all these terms translate is zaveršenie) of the hero by the author in a literary work is viewed as a positive aesthetic achievement in Bakhtin (1990) [1923/4], while the same completion is denounced on ethical grounds as incompatible with true dialogue in Bakhtin (1984) [1929/1963]. But as Erdinast-Vulacan (2013) convincingly argues, this tension hardly represents a clean break in Bakhtin's thought: the ethical critique of completion can already be identified in the early works. Besides, even if we do assume a change of heart on Bakhtin's part, irreducible intersubjectivity is still clearly central to his early thought, and "dialogue" could have been a natural way to refer to it.

${ }^{14}$ A possible additional source could have been Buber (1970) [1923].

15 Though the translation was completed while Bakhtin and Kagan were no longer living in the same city.
} 
by German philosophers, in Marburg and elsewhere. This text is as good a candidate as any to have been a direct influence on Bakhtin, but my argument does not actually depend on this (frankly unverifiable) historical point. Here is the passage in question:

This self-deliverance of the mind is what, since Plato, is called philosophy; what since Kant, who further emphasized and accentuated what Plato meant, we call Critique. It is, simply stated, the understanding of understanding itself from its own deepest grounds, from the rules of Logos. We have already made the meaning of "Word" and its role and significance clear at the first level, the level of immediateness. The unfolding of this self-liberation of Logos through Word and Counter-word, question and answer in mutually fruitful encounter and union, normally when two are present, but also in solitary thought, which always divides itself into question and answer; this exchange of thoughts, in which one wants to make clear to the other not merely his own meaning, but "Meaning" in itself, which makes itself ever more clearly and more deeply understandable: this belongs entirely to the second stage, and amounts to a true schooling of the mind. Word thus becomes speech, which always anticipates a counter-speech in reply, and in fact, when it is clever, it does not wait for this reply to come, but answers it already in advance. Speech is thus much more than speaking, than mere selfexpression. Like a deed, as opposed to mere action, it comprises mutuality, the turn to the other and the expectation of his (expressed or unexpressed) speech and reply. Only then does the word develop its "function" (its duties), and only then is there anything akin to function in mere thought.

Thus understood, speech closely approximates "guidance", as we have explained this term, not as mere recommendation or good advice, but as finding guidance, guiding one's way through, the solution of a problem, finding a way out of the "aporia" (this is not yet knowledge). For the goal of all "development" of thought through dividing itself into speech and counter-speech is becoming one, communication either with oneself, through this inner division, or with another, but doing so from the ground of the matter, from "meaning". Thus Logos becomes Logismos, the simple fact-of-the-matter logic of thought becomes goal-directed logicization in the process of Dialogos, Dialogismos, the always two-sided thinking through (that is, thinking apart and together again); or let us say, "debate" [Auseinandersetzung $]^{16}$ (Natorp 1920, pp. 232-233). ${ }^{17}$

There is a rich concentration of what we would now recognize as "Bakhtinian" themes in these two paragraphs, including some themes developed by Bakhtin much later (arguably also following Vološinov—see Voloshinov 1986 [1929]). Thus, we find much of what will later be recognized as the Bakhtinian account of language, utterance and dialogue in this passage (including, e.g., such features as the addressivity of utterances and their anticipation of their addressee's response-see Bakhtin

${ }^{16}$ Interestingly, when Kagan translates this word into Russian, he uses the word iz iasnenie, which means "clarification", not "debate". Technically speaking, this is just a badly chosen word. But we should also consider the possibility that Kagan had evidence to support this odd reading from his direct communication with his doctoral thesis advisor-Natorp himself.

17 The translation is my own, but is designed to follow Kagan's Russian translation of the text (Natorp 2004 [1920], pp. 148-149) quite closely. I would like to thank Dmitry Bosnak for some useful comments on this text and its interpretation and for locating and making available to me a copy of the book's first edition (which Kagan, and probably Bakhtin too, used). 
1986 [1953/4]). We also find here the distinction between deed and action, central to Bakhtin's (1993) [1921/2] early philosophy. But, again, there are crucial differences in the underlying philosophical framework. Natorp insists on "meaning" as such, which is impersonal, as what interlocutors communicate and on the eventual union of voices in dialogue (Natorp probably has specifically the Platonic dialogue in mind here). Moreover, he grounds his account of dialogue in logic as a starting point.

And this conceptual (and etymological) connection between dialogue and logos is precisely what could make "dialogue" a term to avoid for early Bakhtin. For Natorp, what is important to emphasize in his account is "the ground of the matter", "meaning' in itself", and the eventual "becoming one" of the voices in dialogue. Dialogue itslef is important as a stage, a process in the development of the coming unity of the becoming universal subject. In the grand scheme of things, the existential particularity of the individual subject, of the actual $I$ and the actual thou, can safely be bracketed out. But it is this particularity that Bakhtin makes the ground for his philosophy, and if "dialogue" is understood by his audience as a device for getting rid of such particularity, it should then become a term to avoid.

Again, we have here a pattern that is typical of how Bakhtin appropriates others' work. He adopts a subordinate element from a philosopher's system, while rejecting the headstone of the whole system, which is what, in the original context, gives the adopted element its meaning. ${ }^{18}$ This element then acquires a new meaning-sometimes a radically new meaning —in the new context of Bakhtin's own thought.

The most significant other case in point - which is also directly relevant to the passage from Natorp we just considered-is the constitution of the subject by the other, of the I by the thou. As noted above, this is one of the main pillars of Bakhtin's philosophy. But it is by no means a new idea. Quite to the contrary, at least since Hegel's famous "Lordship and Bondage" section of the Phenomenology of Spirit (see especially Hegel 1977 [1807], §§175-177), the idea that the subject is constituted by the other was one of the leitmotifs of German philosophy up to the early $20^{\text {th }}$ century. However, for Hegel, like all the other philosophers that followed his example, this constitution of the self by others is merely one step on the ladder. The next step invariably involves sublating (or dissolving) the $I$ and the thou into the "higher" unity of a we; into a community or some other form of collective, not individual, subjectivity. It is precisely this "next stage" that Bakhtin rejects, and it is in making this rejection, rather than in the idea of the self being constituted by others as such, that Bakhtin is really breaking new ground.

\footnotetext{
${ }^{18}$ As another example for the same pattern from a different period and thematic context - consider that the second volume of Cassirer's Philosophy of Symbolic Forms, on myth (Cassirer 1955 [1925]), plays a significant role in shaping Bakhtin's conception of carnival in the late 1930s and early 1940s (see Bakhtin 2008 [ca. 1938]; and cf. Poole 1998). Cassirer's third volume (Cassirer 1957 [1929]), dealing with science, which is in many ways the culmination of Cassirer's system, is absent from Bakhtin's discussion.
} 
The sublation of essential intersubjectivity into a uniform and/or collective subject is an antidote to individual subjectivity in the strong sense, which is contained in I-thou relations, and which is poisonous to any theoretical endeavor. The poison has to be neutralized for generalization across individuals to be possible. But Bakhtin's philosophy is grounded in strong subjectivity, in the deed. The constitution of the self by others, the principle of "absolute self-exclusion" (Bakhtin 1993 [1921/2], p. 76), acquires an entirely new meaning and philosophical potency when it is separated from that "antidote", and placed instead into the context of Bakhtin's existential philosophy.

\section{Conclusion}

What defines the originality of a thinker? In Bakhtin scholarship, a tacit assumption has often been that to the extent we can show that Bakhtin borrowed some positions from others before him, we can assume he was not original in arguing for these positions. ${ }^{19}$ This seems to be a logical general assumption to make, but Bakhtin, as we saw, offers a counterexample. Already in his earliest surviving works, Bakhtin combines his different sources into a kind of philosophical pastiche. He can copy whole blocks of interconnected ideas from another thinker, but then place them within the context of his thought so that they begin to serve his own philosophical purposes, which often contrast starkly with those of the thinkers whose work he uses. The result is that the whole construct of Bakhtin's thought is starkly original, even as all of the particular ideas combined in it are borrowed. Indeed, we can say Bakhtin theorized this method of his: Bakhtin tells us in several of his works (e.g., Bakhtin 1981 [1930-6]) that the speaker or author has to adapt, appropriate, the words and voices of previous speakers and authors, to orchestrate these sounds produced by others to form his or her own original meaning, voice, distinct sound.

Another common assumption that this paper hopefully invalidates is that by assigning a thinker to a particular philosophical movement or school, we can justify attributing the positions of the school to the thinker. Bakhtin, as we saw, identified himself as a neo-Kantian, but was in fact very far from neo-Kantian orthodoxy on the most substantial questions.

When today we study Bakhtin's sources of influence, we'd do better to resist the temptation of simply equating Bakhtin with his sources, of applying the usual tools and methods for such studies uncritically, of treating his thought (or any person's thought, for that matter) as if it were merely the logical sum of the propositions expressing his various individual beliefs. Because, at least in Bakhtin's case, identifying sources is important, of course, but it is much more interesting to see how Bakhtin transforms these sources and turns them into the building blocks of his own original philosophy.

19 This seems to be, for instance, the assumption in Poole (2001), and it probably explains Brandist's (2002a, p. 39) statement that Toward a Philosophy of the Act "is of interest chiefly for what it tells us about Bakhtin's later work" and "represents little more than a (rather too) self-conscious combination of themes from contemporary German and Austrian philosophy". 


\section{Acknowledgements}

My work on this paper was partly funded by a Vidi research program (276.70.019, Principal Investigator: E. Pascual) from the Netherlands Organization for Scientific Research (NWO). I would like to thank Craig Brandist and Caryl Emerson for their insightful comments on an earlier draft of the text.

\section{References}

Bakhtin, M. M. (1981) [1930-6]. Discourse in the novel. In The dialogic imagination: Four essays (pp. 259-422). Austin: University of Texas Press.

Bakhtin, M. M. (1984) [1929/1963]. Problems of Dostoevsky's Poetics. Minneapolis: University of Minnesota Press.

Bakhtin, M. M. (1986) [1953/4]. The problem of speech genres. In Speech genres and other late essays (pp. 60-102). Austin: University of Texas Press.

Bakhtin, M. M. (1990) [1923/4]. Author and hero in aesthetic activity. In Art and answerability: Early philosophical essays (pp. 4-256). Austin: University of Texas Press.

Bakhtin, M. M. (1993) [1921/2]. Toward a philosophy of the act. Austin: University of Texas Press.

Bakhtin, M. M. (1996a) [1943]. “Čelovek u zerkala”. In M. M. Bakhtin, Sobranie sočinenij (vol. 5, p. 71). Moscow: Russkie slovari.

Bakhtin, M. M. (1996b) [1943-6]. K voprosam samosoznanija i samootsenki... In M. M. Bakhtin, Sobranie sočinenij (vol. 5, pp. 72-79). Moscow: Russkie slovari.

Bakhtin, M. M. (1996-2012). Sobranie sočinenij. Moscow: Russkie slovari.

Bakhtin, M. M. (2002) [1973]. Besedy s V. D. Duvakinym. Moscow: Soglasie.

Bakhtin, M. M. (2008) [ca. 1938] E. Cassirer "Philosophie der symbolischen Formen. 2.Teil: Das mythische Denken”. Leipzig, 1925. In M. M. Bakhtin, Sobranie sočinenij (vol. 4(1), pp. 785828). Moscow: Jazyki slavianskix kul'tur.

Brandist, C. (2002a). The Bakhtin Circle: Philosophy, culture and politics. London: Pluto Press.

Brandist, C. (2002b). Two Routes "to Concreteness" in the Work of the Bakhtin Circle. Journal of the History of Ideas, 63(3), 521-537.

Brandist, C., Shepherd, D., \& Tihanov, G. (2004). The Bakhtin Circle: A timeline. In C. Brandist, D. Shepherd, \& G. Tihanov (Eds.), The Bakhtin Circle: In the Master's absence (pp. 251-275). Manchester: Manchester University Press.

Buber, M. (1970) [1923]. I and thou. New York: Scribner.

Cassirer, E. (1955) [1925]. The philosophy of symbolic forms. Vol. II: Mythical thought. New Haven, CT: Yale University Press.

Cassirer, E. (1957) [1929]. The philosophy of symbolic forms. Vol. III: The phenomenology of knowledge. New Haven, CT: Yale University Press.

Clark, K., \& Holquist, M. (1984). Mikhail Bakhtin. Cambridge, MA: Harvard University Press.

Cohen, H. (1972) [1919]. Religion of reason out of the sources of Judaism. New York: Frederick Ungar Publishing Co.

Dmitrieva, N. A. (2007). Russkoe neokantianstvo: "Marburg” v Rossii. Moscow: ROSSPEN.

Erdinast-Vulcan, D. (2013). Between philosophy and literature: Bakhtin and the question of the subject. Stanford, CA: Stanford University Press.

Fryszman, A. (1996). Kierkegaard and Dostoyevsky seen through Bakhtin's prism. Kierkegaardiana, $18,100-125$.

Gogotišvili, L. A. (1996). Commentary. In M. M. Bakhtin, Sobranie sočinenij (vol. 5). Moscow: Russkie slovari.

Gogotišvili, L. A. (2003). Commentary. In M. M. Bakhtin, Sobranie sočinenij (vol. 1, pp. 351-438). Moscow: Russkie slovari.

Hegel, G. W. F. (1977) [1807]. Phenomenology of spirit. Oxford: Clarendon Press.

Holquist, M. (1990). Dialogism: Bakhtin and his world. London: Routledge. 
Kagan, M. I. (2004a) [1922]. Avtobiografija 1922-go goda. In M. I. Kagan, O xode istorii (p. 23). Moscow: Iazyki slavianskoj kul'tury.

Kagan, M. I. (2004b) [1924/5]. Avtobiografičeskie zametki. In M. I. Kagan, O xode istorii (pp. 24 27). Moscow: Iazyki slavianskoj kul'tury.

Kagan, M. I. (2004c) [1920/1]. German Kogen. "Religija razuma iz istočnikov iudejstva" (Konspekt). In M. I. Kagan, O xode istorii (pp. 45-92). Moscow: Iazyki slavianskoj kul'tury.

Kagan, M. I. (2004d) [1922]. Hermann Cohen (4 July 1842-4 April 1918). In C. Brandist, D. Shepherd, \& G. Tihanov (Eds.), The Bakhtin Circle: in the master's absence (pp. 193-211). Manchester: Manchester University Press.

Kant, I. (1929) [1781/7]. Critique of pure reason. New York: Macmillan.

Kant, I. (2004) [1783]. Prolegomena to any future metaphysics. Cambridge: Cambridge University Press.

Kierkegaard, S. (1992) [1846]. Concluding unscientific postscript to Philosophical fragments. Princeton, NJ: Princeton University Press.

Melixova, L. S. (2000). Commentary. In M. M. Bakhtin, Sobranie Sočinenij (vol. 2, pp. 560-654). Moscow: Russkie slovari.

Mirkina, R. M. (1993). Bakhtin, kakim ja ego znala (Molodoj Bakhtin). Dialog. Karnaval. Xronotop, (2), 92-96.

Morson, G. S., \& Emerson, C. (1990). Mikhail Bakhtin: Creation of a prosaics. Stanford, CA: Stanford University Press.

Natorp, P. (1920). Sozial-Idealismus. Berlin, Heidelberg: Springer Berlin Heidelberg.

Natorp, P. (2004) [1920]. Paul' Natorp. "Sotsial'nyj idealizm". In M. I. Kagan, O xode istorii (pp. 98149). Moscow: Iazyki slavianskoj kul'tury.

Nikiforov, V. (2006). The collapse of philosophy and its rebirth: An intellectual history with special attention to Husserl, Rickert and Bakhtin. Lewiston: The Edwin Mellen Press.

Nikolaev, N. I. (2001). Introduction to M. M. Bakhtin's lectures and comments from 1924-1925: from the notebooks of L. V. Pumpiansky. In S. M. Felch \& P. J. Contino (Eds.), Bakhtin and religion: a feeling for faith (pp. 194-205). Evanston, IL: Northwestern University Press.

Nikolaev, N. I., \& Liapunov, V. (2003). Commentary. In M. M. Bakhtin, Sobranie sočinenij (vol. 1, pp. 492-503). Moscow: Russkie slovari.

Poole, B. (1995). "Nazad k Kaganu”: Marburgskaia škola v Nevele i filosofia M. M. Bakhtina. Dialog. Karnaval. Xronotop, (10), 38-48.

Poole, B. (1997). Rol' M. I. Kagana v stanovlenii filosofii M. M. Bakhtina (ot Germana Kogena k Maksu Sheleru). In V. L. Makhlin (Ed.), Bakhtinskij sbornik III (pp. 162-181). Moscow: Labirint.

Poole, B. (1998). Bakhtin and Cassirer: The philosophical origins of Bakhtin's carnival messianism. The South Atlantic Quarterly, 97(3/4), 537-578.

Poole, B. (2001). From phenomenology to dialogue: Max Scheler's phenomenological tradition and Mikhail Bakhtin's development from "Toward a philosophy of the act" to his study of Dostoevsky. In K. Hirschkop \& D. Shepherd (Eds.), Bakhtin and cultural theory (2nd ed., pp. 109-135). Manchester: Manchester University Press.

Sandler, S. (2012). Whose words are these anyway? In M. Polyuha, C. Thomson, \& A. Wall (Eds.), Dialogues with Bakhtinian theory (pp. 227-242). London, Ontario: Mestengo Press.

Ščittsova, T. V. (1999). K istokam ekzistentsial'noj ontologii: Paskal', Kirkegor, Bakhtin. Minsk: Propilei.

Voloshinov, V. N. (1986) [1929]. Marxism and the philosophy of language. Cambridge, MA: Harvard University Press.

Yakubinsky, L. P. (1997) [1923]. Lev Petrovich Yakubinsky on Dialogic Speech. PMLA, 112(2), 243-256. 